\title{
DO PERSONALITY TRAITS PREDICT BIASEDNESS WHILE MAKING INVESTMENT DECISIONS?
}

\author{
Ashutosh Yadav \\ Assistant Professor \\ Hansraj College \\ University of Delhi, India \\ E-mail: ashutosh@hrc.du.ac.in \\ G. Badri Narayanan \\ Senior Economist \\ School of Environmental and Forestry Sciences \\ University of Washington, Seattle, USA \\ E-mail: badrig@uw.edu
}

\begin{abstract}
The Investors' rationality assumption of traditional finance theories has long been contested by behavioural finance over the past few decades. Various non-financial factors, responsible for shaping investors' behaviour, including individual personality characteristics and the social environments surrounding the decisions to be made, have emerged in recent studies. With the advancement of behavioural finance, it is important to recuperate our understanding of how an individual's personality make-up influences her susceptibility towards behavioural biases while making investment decisions. In this study, we explore the effect of the five personality traits on select behavioural biases (overconfidence, disposition and herding) in financial decision-making. A questionnaire comprising measures of personality traits, overconfidence and herding along with demographic variables was circulated to a representative sample $(n=251)$ of Indian investors. Our findings suggest a significant impact of personality traits on the vulnerability of individuals while making investment decisions. Extrovert investors are more balanced, not overconfident, and do not follow the herd. Openness, extroversion, and agreeableness negatively impact the susceptibility of investors towards overconfidence and herding. The results can be used by financial advisors to develop personality specific financial tools to customise to the requirements of their clients.
\end{abstract}

Keywords: Investment Decision Making, Behavioural Biases, Overconfidence, Herding, Personality Traits.

JEL Classification Codes: D14, D90, D91, G11.

\section{INTRODUCTION}

Financial decisions are influenced by non-financial factors. These include context factors as well as the personality characteristics of individuals, thus moderating the way in which the environment affects decisions (Holden, 2010). Individual investors face difficulties making investment decisions due to lack of financial sophistication (Winchester, Huston, \& Finke, 2011). The propensity to act cautiously and maintain a balanced optimum investment portfolio in the face of falling security prices entails the ability to avoid behavioural instincts when making long-term asset allocation decisions (Winchester et al., 2011). Investment 
decision-making of individual investors can be considered as an intricate behavioural process which is influenced by rational and irrational factors which contribute to inefficiency of security markets (Shanmugham \& Ramya, 2012).

There is extant literature arguing that these market inefficiencies fail the standard finance models underlying the 'efficient market'. These anomalies in the security market have generally been ascribed to behavioural biases of investors. This has been accepted and evidenced by Odean (1998), Odean (1999), Barber and Odean (2000) and Barber and Odean (2001) amongst others. Every investor possesses unique physiognomies due to a host of demographic, psychological, and personality factors. The proneness of an investor to a particular illusion is likely to be a function of these variables.

Investors' personality plays a vital role in determining their behaviour and thus influences their decision (Sadi, Asl, Rostami, Gholipour, \& Gholipour, 2011); (Charles \& Kasilingam, 2014); (Zaidi \& Tauni, 2012); (Durand, Newby, \& Sanghani, 2008); (Durand, Newby, Peggs, \& Siekierka, 2013a); (Durand, Newby, Tant, \& Trepongkaruna, 2013b). Personality is the culmination of all the attributes, physiognomies, and idiosyncrasies that one possesses, encompassing all the traits which set apart the personality of each individual.

Personality has a stronghold on economic practices and informs our values, decisions and thought process. It would be unfair to assume that finance is immune to it. This study focuses explicitly to adduce the impact of personality on investment decision making in finance and to disentangle the psychological dimension of this field in order to unravel the mystery behind some of the unexplained anomalies in the financial markets. The paper provides substantial evidence of impact of personality traits on the susceptibility of individual investors towards two of the most prevalent behavioural biases i.e., herding and overconfidence bias, in investment decisions making.

Individuals make systematic errors while making decisions owing to too much reliance on recent experiences, overconfidence, and preference to perceive things differently. This preference may twist the decision outcome and thus severely impact investment decision making (Subrahmanyam, 2007). Individuals' predisposition to make certain decisions is a function of the type of person the individual is i.e., an individual's personality impacts the decisions s/he makes (Durand et al., 2008); (Durand et al., 2013a).An individual's cognitive abilities of information processing, analysis and alternative evaluation, are all influenced by his personality.

Pennings and Garcia (2009) found that retail investors avoid making rational decisions, in general, and would instead base their decisions on behavioural factors viz. mental accounting, cognitive dissonance, anchoring, greed, fear, and heuristics.

Chaudhary (2013), on observing the irrational financial decisions of investors, established that emotional and cognitive factors in form of loss aversion, overconfidence, anchoring, over and under reaction and herd behaviour, have a strong influence on investors' decision-making process.

Similarly, Chaffai and Medhioub (2014) conducted a study in Tunisia which concluded that small investors base their decisions on behavioural biases and market efficiency. It emerges from the literature that individual and even institutional investors have incorporated heuristics or rule of thumb in the process of investment decision making (Rehan \& Umer, 2017).

The overconfidence effect has been defined by Gigerenzer, Hoffrage, and Kleinbolting (1991) as occurring "when the confidence judgments are larger than the relative frequencies of the correct answers". When people are not well calibrated, they tend to have too strong a belief in the precision of their decisions and become overconfident, i.e., they tend to believe that they know more than they actually do or that the accuracy of their decisions is higher than it actually is. Over-confidence has been referred to as a "cognitive conceit" by 
Block and Harper (1991). Odean (1998) introduced the concept of overconfidence as investors' tendency to overestimate the precision of their knowledge about the value of a security.

Seminal contributions of many researchers familiarized the concept of herding into financial literature to emphasize its impact on the overall mechanism of financial markets (Campenhout \& Verhestraeten, 2010); see also (Bikhchandani, Hirshleifer, \& Welch, 1992); (Scharfstein \& Stein, 1990); (Shiller, 1987) and (Banerjee, 1992). Bikhchandani et al. (1992) defined herding as imitation behaviour resulting from individual factors and leading to market inefficiencies. Banerjee (1992) defined herding as "everyone doing what everyone else is doing, even when their private information suggests doing something quite different."

Studies that have explored these relationships, for both the biases, have been summarized below:

Table 1. Literature Summary: Big Five and Overconfidence and Herding

\begin{tabular}{|c|c|c|c|c|c|}
\hline \multirow{2}{*}{$\begin{array}{l}\text { Relation } \\
\text { Traits }\end{array}$} & \multicolumn{2}{|l|}{ Positive } & Negative & \multicolumn{2}{|c|}{ Insignificant } \\
\hline & Overconfidence & Herding & Overconfide & ice & Herding \\
\hline 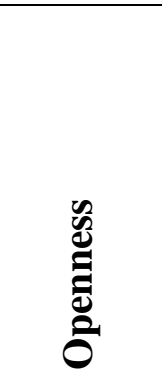 & $\begin{array}{l}\text { Kubilay and } \\
\text { Bayrakdaroglu } \\
\text { (2016); Sadi et al. } \\
\text { (2011); } \\
\text { Lin (2011); } \\
\text { Jamshivinavid et al. } \\
\text { (2012); } \\
\text { Jency (2017) }\end{array}$ & $\begin{array}{l}\text { Jamshidinavid et } \\
\text { al. (2012); } \\
\text { Lin (2011); } \\
\text { Bashir et al. } \\
(2013) \text {; } \\
\text { Bayrakdoruglu, } \\
\begin{array}{l}\text { San, and Oztop } \\
(2015)\end{array}\end{array}$ & $\begin{array}{l}\text { Bashir et al. } \\
(2013)\end{array}$ & $\begin{array}{l}\text { Zaidi and } \\
\text { Tauni } \\
(2012)\end{array}$ & - \\
\hline 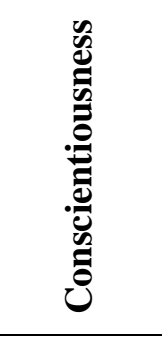 & $\begin{array}{l}\text { Jamshidinavid et al. } \\
\text { (2012); Lin (2011); } \\
\text { Jamshidinavid et al. } \\
\text { (2012); Bashir et al. } \\
\text { (2013); Thomas } \\
\text { (2014); Jency } \\
\text { (2017) }\end{array}$ & - & - & $\begin{array}{l}\text { Schaefer et } \\
\text { al. (2004) }\end{array}$ & $\begin{array}{l}\text { Lin (2011); } \\
\text { Jamshidina } \\
\text { vid et al. } \\
(2012)\end{array}$ \\
\hline 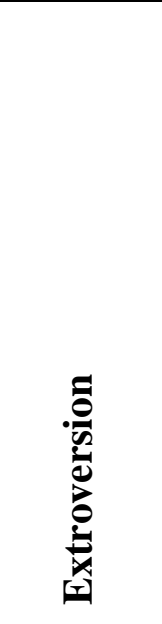 & $\begin{array}{l}\text { Durand et al. } \\
\text { (2012); Durand et } \\
\text { al. } \\
\text { Lin (2013b); } \\
\text { Jamshidinavid et al. } \\
\text { (2012); } \\
\text { Bayrakdaroglu and } \\
\text { (2016); Zaidi \& } \\
\text { Tauni (2012); } \\
\text { Bashir et al. (2013); } \\
\text { Pan and Statman } \\
\text { (2013); } \\
\text { (2017) Jency }\end{array}$ & Lin (2011) & $\begin{array}{l}\text { Thomas } \\
\text { (2014) }\end{array}$ & - & $\begin{array}{l}\text { Jamshidina } \\
\text { vid et al. } \\
(2012)\end{array}$ \\
\hline
\end{tabular}




\begin{tabular}{|c|c|c|c|c|c|}
\hline 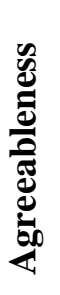 & $\begin{array}{l}\text { Zaidi and Tauni } \\
(2012) ; \text { Kubilay \& } \\
\text { Bayrakdaroglu } \\
(2016) ; \\
\text { Bashir et al. (2013), } \\
\text { Jency (2017) }\end{array}$ & $\begin{array}{l}\text { Jamshidnavid et } \\
\text { al. (2012); } \\
\text { Bayrakdaroglu et } \\
\text { al. (2015); } \\
\text { Raheja \& Dhiman } \\
(2017)\end{array}$ & $\begin{array}{l}\text { Pan } \\
\text { Statman } \\
(2013)\end{array}$ & $\begin{array}{l}\text { Shaefer et } \\
\text { al. (2004); } \\
\text { Lin } \\
(2011) ; \\
\text { Sadi et al. } \\
(2011)\end{array}$ & - \\
\hline 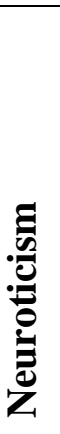 & $\begin{array}{l}\text { Campbell, Goodie } \\
\text { and Foster (2004); } \\
\text { Bashir et al. (2013); } \\
\text { Thomas (2014) }\end{array}$ & 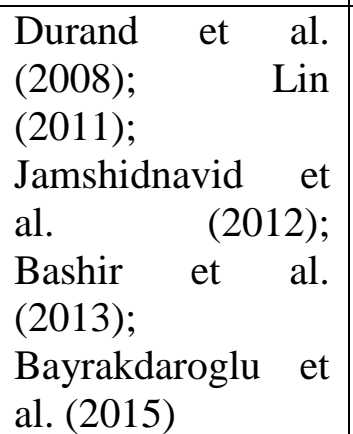 & $\begin{array}{l}\text { Zaidi an } \\
\text { Tauni } \\
(2012)\end{array}$ & $\begin{array}{l}\text { Shaefer et } \\
\text { al. }(2004) \text {, } \\
\text { Lin } \\
(2011) \text {; } \\
\text { Jency } \\
(2017)\end{array}$ & - \\
\hline
\end{tabular}

Source: Author's own compilation

For the purpose of assessing the personality type of the respondents, the Big Five personality inventory has been taken. Durand et al. (2008) reported that the "Big Five" personality inventory, the psychosomatic gender concepts of masculinity and femininity, preference for innovation and risk-taking tendency are related with the investment decisions. The most extensive framework of personality is the "Big Five," or the personality's fivefactor model owing to the fact that this theory of personality has been documented to apply across multiple countries and cultures across the world. It is one of the most valid and reliable measurement scales for these five factors (Schmitt, et al., 2007). This study used BFI recreated by John and Srivastava (1999). It includes 44 items and measures each dimension through its related aspects.

The following list demonstrates the Big Five Factors as identified by and proposed by Goldberg (1992):

- Extroversion

- Agreeableness

- Conscientiousness

- Neuroticism

- Openness to experience

The study tries to test a theoretical model of personality's influence on the susceptibility of stock market investors to these two behavioural biases. Accordingly, the following hypothesis has been formed:

- H0 $\mathbf{0}_{1}$ : Extroversion does not have a significant impact on susceptibility towards overconfidence bias among stock investors.

- $\mathbf{H O}_{2}$ : Agreeableness does not have a significant impact on susceptibility towards overconfidence bias among stock investors

- $\mathbf{H O}_{3}$ : Conscientiousness does not have a significant impact on susceptibility towards overconfidence bias among stock investors.

- $\mathbf{H O}_{4}$ : Neuroticism does not have a significant impact on susceptibility towards overconfidence bias among stock investors.

- H05: Openness does not have a significant impact on susceptibility towards overconfidence bias among stock investors.

- H06: Extroversion does not have a significant impact on susceptibility towards herding bias among stock investors. 
- H0: Agreeableness does not have a significant impact on susceptibility towards herding bias among stock investors.

- H0: Conscientiousness does not have a significant impact on susceptibility towards herding bias among stock investors.

- H09: Neuroticism does not have a significant impact on susceptibility towards herding bias among stock investors.

- H0 $\mathbf{1 0}_{\mathbf{1 0}}$ : Openness does not have a significant impact on susceptibility towards herding bias among stock investors.

\section{METHODOLOGY}

The study employs a quantitative, non-experimental, correlation, explanatory and crosssectional research design. For the primary data collection to gauge responses from investors, structured questionnaire has been prepared using available literature.

To specify the population, only those investors who invest in stock markets have been included. Investors of mutual funds have been excluded from the population as most of the mutual funds' investors are engaged in indirect/passive investing. The respondents have been chosen from the Delhi-NCR region for the reason that it is one of the few states to have more than $5 \%$ of its population who invest in stock markets (BSE, CMIE and Mint Calculations, n.d.).

The survey was administered online by sending emails and messages via Linked-in to investors and broker firms, as well as on a one-to-one basis by visiting a few broker firms. In total, 251 responses were received that were taken up for the analysis.

For data instrumentation, the initial grounds were narrowed down from the extant literature on personality and behavioural biases and thus assimilated into the proposed personality-biases model. However, each item was meticulously observed in the light of the requirements of the study so as to avoid any unwarranted, ineffectual statement and complicated questions (Whitely, 2002). Consequently, few statements were rephrased and revised to suit the Indian context.

For analysing the aforementioned relationships between the model's dependent and independent variables, Structural Equation Modelling (SEM) has been used in this study.

\section{RESULTS ANALYSIS}

The data was screened for missing values, unengaged responses, normality, and outliers using Mahalanobis distance (MD).Responses having both $\mathrm{p} 1$ and $\mathrm{p} 2$ values less than 0.05 were deleted. In total, 39 responses have been deleted on account of unengaged response and outliers reducing number of workable responses to 218 .

Table 2 presents the frequency distribution of the final 218 respondents in different groups considered after accounting for outliers across demographic and sophistication variables:

Table 2. Demographic Profile of the Respondents

\begin{tabular}{|c|c|c|c|c|c|c|c|c|c|c|}
\hline \multicolumn{11}{|c|}{ Demographics } \\
\hline \multicolumn{2}{|c|}{ Gender } & \multicolumn{2}{|c|}{ Education } & \multicolumn{4}{|c|}{ Occupation } & \multicolumn{3}{|c|}{$\begin{array}{l}\text { Personal Monthly } \\
\text { Income }\end{array}$} \\
\hline Male & Female & $\begin{array}{l}\text { Graduate } \\
\text { and } \\
\text { Below }\end{array}$ & $\begin{array}{l}\text { Post } \\
\text { Graduate } \\
\text { and } \\
\text { Above }\end{array}$ & Employed & Profession & Business & Unemployed & $<25 \mathrm{k}$ & $\begin{array}{l}25 \mathrm{k}- \\
50 \mathrm{k}\end{array}$ & $>50 \mathrm{k}$ \\
\hline
\end{tabular}




\begin{tabular}{|c|c|c|c|c|c|c|c|c|c|c|}
\hline 87.2 & 12.8 & 48.6 & 41.4 & 47.7 & 13.8 & 19.7 & 18.8 & 25.7 & 25.2 & 49.1 \\
\hline \multicolumn{11}{|c|}{ Investor Sophistication } \\
\hline \multicolumn{4}{|c|}{ Trading Frequency } & \multicolumn{3}{|c|}{ Experience } & \multicolumn{4}{|c|}{ No. of Securities in Portfolio } \\
\hline 1 & $1-3$ & $4-8$ & $8+$ & $<3$ years & $3-10$ years & $\begin{array}{l}>10 \\
\text { years }\end{array}$ & $1-3$ & $3-7$ & $7+$ & \\
\hline 11.9 & 45.9 & 15.6 & 26.6 & 54.1 & 27.1 & 18.8 & 25.2 & 37.6 & 37.2 & \\
\hline
\end{tabular}

The internal consistency of the measurement instrument has been assessed using Cronbach's Alpha, Spearman Brown's Coefficient, and Guttman's Split Half Coefficient by testing all factors. The test results show a correlation value of 0.816, Spearman Brown's Split Half and Guttman Split Half coefficients show good reliability to the extent of 0.901 and 0.890 respectively for Overconfidence and a correlation value of 0.707 for herding. Spearman Brown's Split Half and Guttman's Split Half coefficients show good reliability to the extent of 0.755 and 0.751 respectively for herding, good reliability to the extent of 0.748 and 0.705 respectively for Agreeableness, reasonable reliability to the extent of 0.684 and 0.680 respectively for Conscientiousness, reasonable reliability to the extent of 0.694 and 0.690 respectively for Neuroticism, and poor reliability to the extent of 0.631 and 0.531 respectively for Openness but have been considered given the overall Cronbach's Alpha score.

\section{Measurement Model}

Each latent construct to be included in the model is identified, and measure indicator/ manifest variables are assigned to individual latent constructs. The measurement model was run using the maximum likelihood estimation method as recommended by Hair et al. (2010). The Confirmatory Factor Analysis (CFA) results for the initial model reports 703 distinct sample moments with 87 distinct parameters identified to be estimated; 616 degrees of freedom and a Chi-square value of 2092.30 for the model. The output from the model reports that the minimum iteration is reached, thereby rendering confidence that the estimation process generated an acceptable solution, dismissing any concern about multicollinearity effects.

The calculations of all the validity parameters have been carried out using the Master Validity Tool by Gaskin \& Lim (2016). In order to check the validity of the model, the maximum likelihood factor loading estimates, their magnitude direction, and statistical significance are evaluated. The results confirmed that all loadings in the specified model are not significant. The items below the threshold were candidates for elimination. Average Variance Extracted measures for neuroticism and herding are less than 0.50, thereby indicating convergent validity issues. Composite Reliability (CR) value indicates that the overall reliability of items loaded on neuroticism and herding does not fall above the acceptable limit. The chi-square goodness of fit indicates that the observed covariance matrix does not match the estimated covariance matrix within sampling variances. RMSEA (Root Mean Squared Error of Approximation), which is an Absolute Fit Index (AFI), has a value of 0.099 and hence unacceptable (Awang, 2012). The value of RMR (Root Mean square Residual) is 0.315 which is above the cut-off limit of 0.08 as recommended by $\mathrm{Hu}$ and Bentler (1999). Moving with the incremental fit index, the CFI (Comparative Fit Index) value of 0.559 , falls below the CFI standard of 0.90 for a model of this complexity ( Hair et al., 2010); see also Hu and Bentler (1999); Awang (2012)\}.

The model was corrected for fitness, convergent validity, and discriminate validity. The statements having factor loadings less than 0.05 were deleted initially to check if the model achieves fitness and validity thresholds. 
After eliminating the statements on the basis of standardized loading estimates, AVE and CR and accommodating for Modification Indices (MIs), and carrying out many deliberations, the final measurement model was arrived at which was then analysed for fitness again as recommended by Byrne (1998); Kline (2005); and Hair et al. (2010). In our model, a correlation has been drawn between error terms of E3 and E6.

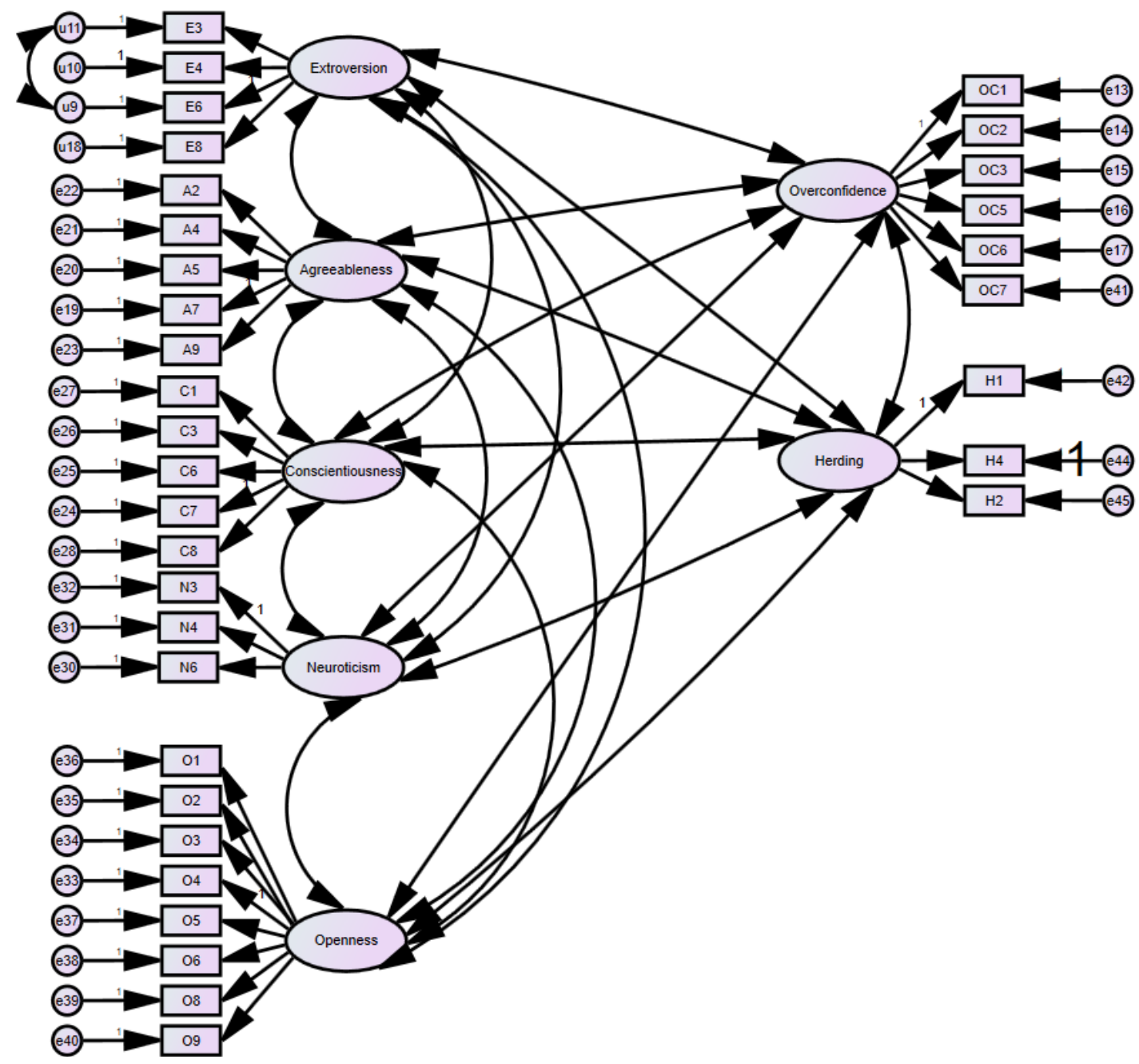

Figure 1. Revised Measurement Model

Note: Initial measurement model has not been presented in the study.

The reliability of the corrected model improved to $0.909,0.665,0.858,0.905,0,876$, 0.678 and 0.796 for Overconfidence, Herding, Extroversion, Agreeableness, Conscientiousness, Neuroticism, and Openness respectively.

The revised model CFA results report 595 distinct sample moments with 90 distinct parameters identified to be estimated; 505 degrees of freedom and a Chi-square value of 882.066 for the model. In this model, the minimum iteration is attained, thereby providing an assurance that the estimation process yields an admissible solution, eliminating any concern about multicollinearity effects. The model is an over-identified one, thus, meeting our requirement for the model to be estimated. No problems would emerge with the rank condition as the study has at least three indicators for each construct.

The fitness indices measures have improved tremendously and moved closer to the threshold limits. In our CFA model, CFI has a value of 0.928 , which exceeds the CFI guidelines of greater than 0.90 for a model of this complexity and sample. The other 
incremental indices also suggest a good model fit. Similarly, factor loadings of the corrected model met the threshold limits to meet the criterion for construct validity.

The validity analysis on revised model reports that almost all the issues related to construct validity and discriminate validity have been accounted for. The CR values are not only greater than 0.70 but close to 0.90 indicating high reliability for all the variables, except for neuroticism. It lies between $0.60-0.70(0.687)$ and hence, is acceptable if other indicators of the construct's validity are good (Hair et al., 2010). Similarly, the AVE measure should be greater than 0.50 , and in this model, the value is less than 0.50 i.e., 0.445 for Neuroticism and 0.451 for Herding but it is too close to 0.50 and thus can be taken up for further analysis.

Based on these results, structural model has been specified in Figure 2.

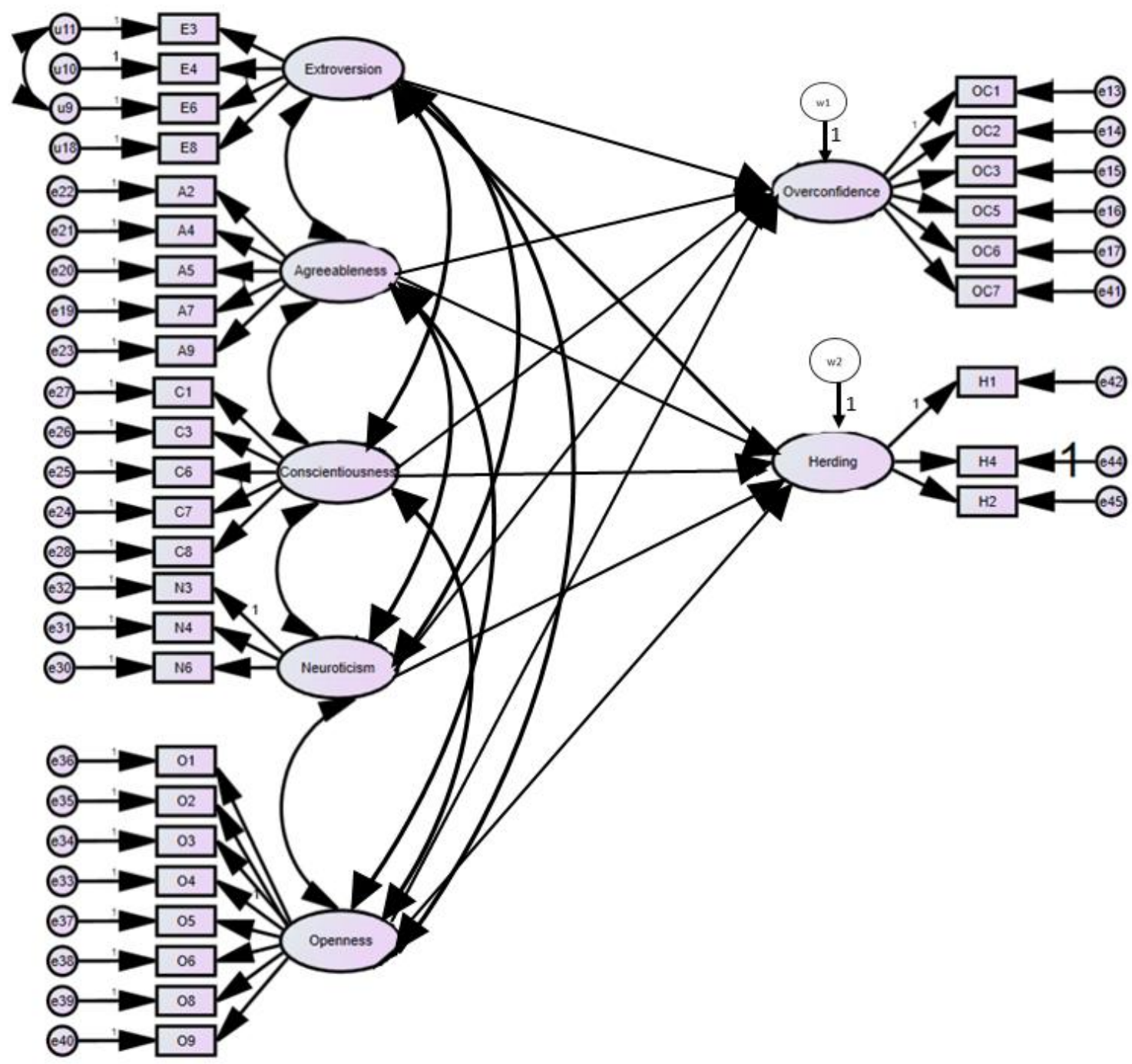

Figure 2. Structural Model

To avoid complexity, the present study has used data imputation to simplify the model and our analysis thereof. The fit indices indicate that the hypothesized structural model provided the good fit to the data. The likelihood ratio chi-square, $\chi 2=882.286$; $\mathrm{DOF}=5006$; $\mathrm{p}=.000$ ); other fit measures show that the model adequately fit the observed data. The incremental fit measure, i.e., CFI is 0.928 , and absolute fit measures, i.e., RMR and RMSEA are 0.068 and 0.059 respectively which are above the minimum requirement showing 
adequate fit, thus, indicating a good fit of the model. In addition to these indices, the $\chi^{2}$ / DOF $=1.744$ was within the threshold level (i.e., $1.0<\chi 2 / \mathrm{DOF}<3.0$ ) supporting these findings.

The model is then run for regression for analysing the impact of individual personality traits on overconfidence and herding. Table 3 presents the results of the regression analysis:

Table 3. Regression Analysis: Model Summary and ANOVA Results

\begin{tabular}{|l|l|l|l|l|l|l|}
\hline Model & R & R Square & $\begin{array}{l}\text { Adjusted R } \\
\text { Square }\end{array}$ & $\begin{array}{l}\text { Std. Error } \\
\text { of } \\
\text { Estimate }\end{array}$ & F Statistics & P Value \\
\hline 1 & 0.875 & 0.766 & 0.761 & 0.4218 & 139.114 & 0.00 \\
\hline 2 & 0.831 & 0.69 & 0.683 & 0.41293 & 94.457 & 0.00 \\
\hline $\begin{array}{l}\text { Model 1: Predictors: (Constant), Extroversion, Agreeableness, Conscientiousness, Neuroticism, } \\
\text { Openness Dependent Variable: Overconfidence }\end{array}$ \\
\hline $\begin{array}{l}\text { Model 2: Predictors: (Constant), Extroversion, Agreeableness, Conscientiousness, Neuroticism, } \\
\text { Openness } \\
\text { Dependent Variable: Herding }\end{array}$ \\
\hline
\end{tabular}

For the first set of regression, the value of $\mathrm{R}$ comes out to be 0.875 , and the value of $\mathrm{R}$ Square is 0.766 implying that the personality traits explain $76.6 \%$ of the variance of the Overconfidence bias. The value of F-Ratio is 139.114, indicating that the model is significant in predicting the outcome since $\mathrm{p}<0.05$. For the second set of regression, the value of $\mathrm{R}$ is 0.831 , and the value of R Square is 0.690 implying that the personality traits explain $69.0 \%$ of the variance of the herding bias. The adjusted $\mathrm{R}$ Square is 0.683 . The value of F-Ratio is 94.457, thus, indicating that the model is significant in predicting the outcome since $p<0.05$.

Table 4. Regression Analysis: Coefficients

\begin{tabular}{|c|c|c|c|c|c|c|c|c|c|c|}
\hline \multicolumn{6}{|c|}{ Overconfidence and Personality Factors } & \multicolumn{5}{|c|}{ Herding and Personality Factors } \\
\hline & \multicolumn{2}{|c|}{$\begin{array}{l}\text { Unstandardized } \\
\text { Coefficients }\end{array}$} & \multirow{2}{*}{$\begin{array}{l}\text { Standardized } \\
\text { Coefficients } \\
\text { Beta }\end{array}$} & \multirow{2}{*}{$\mathbf{T}$} & \multirow{2}{*}{$\begin{array}{l}\mathbf{P} \\
\text { Value }\end{array}$} & \multicolumn{2}{|c|}{$\begin{array}{l}\text { Unstandardized } \\
\text { Coefficients }\end{array}$} & \multirow{2}{*}{$\begin{array}{l}\text { Standardized } \\
\text { Coefficients } \\
\text { Beta }\end{array}$} & \multirow{2}{*}{$\mathbf{T}$} & \multirow{2}{*}{$\begin{array}{l}\mathbf{P} \\
\text { Value }\end{array}$} \\
\hline & $\mathbf{B}$ & $\begin{array}{l}\text { Std. } \\
\text { Error }\end{array}$ & & & & B & $\begin{array}{l}\text { Std. } \\
\text { Error }\end{array}$ & & & \\
\hline (Constant) & 0.575 & 0.155 & & 3.697 & 0.00 & 0.002 & 0.152 & & 0.016 & 0.99 \\
\hline Extroversion & -2.67 & 0.185 & -2.448 & -14.38 & 0.00 & -2.1 & 0.181 & -2.267 & -11.57 & 0.00 \\
\hline Agreeableness & -3.13 & 0.232 & -3.117 & -13.47 & 0.00 & -2.3 & 0.227 & -2.699 & -10.13 & 0.00 \\
\hline Conscientiousness & 9.531 & 0.624 & 9.852 & 15.282 & 0.00 & 9.619 & 0.611 & 11.698 & 15.756 & 0.00 \\
\hline Neuroticism & -0.08 & 0.055 & -0.069 & -1.375 & 0.17 & 0.945 & 0.054 & 1.004 & 17.435 & 0.00 \\
\hline Openness & -4.01 & 0.399 & -3.824 & -10.05 & 0.00 & -6.49 & 0.39 & -7.289 & -16.63 & 0.00 \\
\hline
\end{tabular}

The results of the regression analysis give us the value of the beta coefficient for all the independent variables. As depicted from the Table 4, the p-value for all the independent variables except for Neuroticism is statistically significant for both the biases. Since $p<0.05$ in all cases except for neuroticism, we do not reject the null hypothesis, i.e., personality factors except for neuroticism significantly impact the susceptibility of stock investors towards overconfidence bias. Similarly, we can conclude that all the personality factors significantly impact the susceptibility of stock investors towards herding bias. 


\section{DISCUSSION}

Behavioural finance has emerged tremendously in the contemporary times and so have its implications in the stock markets. What causes the market fluctuations are not just the events but how the investors react to such events. These reactions are the offspring of the prevalence of behavioural biases among investors and tend to have prolonged consequences.

Highlighting the importance of incorporating personality in investment decisionmaking, this study has clear and far-reaching implications. As revealed by the results, personality is one of the crucial factors significantly impacting behavioural biases and thus, the investment decision-making process. Investors with low openness, high conscientiousness and low extroversion are more likely to be susceptible to overconfidence bias and as such overconfidence can be detected in such investors. Investors with low openness, high conscientiousness, low extroversion, low agreeableness, and high neuroticism are more likely to be susceptible to herding bias and as such herding tendencies can be detected in such investors.

Extroverts investors enjoy being with people, participate in social gatherings, and are active and very friendly. Extroversion should not be often confused with openness which implies open-minded and authority challenging attitude. Extroverts tend to communicate more with others, and in the process, they exchange ideas and gather more information, becoming more informative. This tendency then influences their decision-making process, making them less overconfident and thus, extroversion negatively impacts susceptibility towards overconfidence bias amongst investors.

Regarding the herding behaviour, the possible reasons underlying the negative relationship with extroversion could be attributed to the nature of extrovert investors which are likely to help investors to avoid herding bias. Such individuals are assertive, energetic, optimistic, talkative, and outgoing. Interaction and confidence are other attributes of such individuals. They interact with people but at the same time are confident of their stance. They might consider opinions of others but not necessarily follow others blindly and hence do not base their investment decisions entirely on others' advice.

Agreeable individuals are more empathetic and altruistic. In Psychology, agreeableness measures one's tendency to be kind, empathetic, trusting, cooperative, modest and sympathetic. One of the essential characteristics of such investors is avoiding anger and aggression, and hence their decisions are most likely well thought of. This is so because of their cooperative nature. Agreeableness, thus, tend to negatively impact susceptibility towards overconfidence bias amongst investors. Our results are in sync with Pan and Statman (2013) and Bashir et al. (2013), whose results proved that overconfidence is relatively low among those with high levels of agreeableness. Investors with this trait are highly receptive of the information from others and in the process form a better informed and more rational decision based on the available information. Listening is one of the most crucial skills to be informative and intelligent. Thus, people with high agreeableness factor are less susceptible to herding bias.

Individuals high on conscientiousness show an awareness of the impact that their own behaviour has on those around them. These individuals tend to be oriented towards their motives, driven in their efforts at work and feel relaxed and content when they are thoroughly prepared and organized. Investors with such trait believe that their own performance is better than other investors. With this attribute, investors are more confident and thus would be prone to overconfidence bias.

Conscientiousness is a relatively stable trait that captures an investor's tendencies toward order, thoroughness, achievement, and planning. Conscientious people tend to be productive and organized as opposed to easy-going and chaotic. They dedicate their efforts to invest in their financial future. They prefer structure while investment decision making. Such 
individuals, in a bid to follow the order and their set plans, tend to compromise on spontaneity and become less flexible. Once they have formed a viewpoint that the market is moving in a particular direction, seldom do they change their decisions. They tend to generally follow the herd. Conscientiousness, thus, positively impacts susceptibility towards herding bias amongst investors.

Neuroticism is generally associated positively with risk aversion due to their timid and nervous nature. When neurotic investors anticipate a negative outlook for their investments, they can experience stress and anxiety. This can be ascribed to the fact that neurotics are poor in responding to financial and investment stressors. They lack coping strategies or psychosocial support. In scenarios of stress, anxiety and uncertainty, they seek advice from their friends, relatives, reports from financial planners and thus, have tendencies to follow the herd.

Individuals who are open- minded, intellectual and ready to experience new things are less likely to be prone to overconfidence. Such individuals seek new information on a continual basis, and in this process, they become more aware of the different possible outcomes of their decisions, make the judicious use of all the available information and thus, are less likely to follow the herd. Also, this trait is accompanied by creativity, imagination, and intellect. These investors are sure to make their own well-informed decisions based on the available information.

The knowledge about personality traits of their prospective clients may help financial advisors build customized and modified investing plans for the clients. They can take the personality diagnostic tests of their clients and then build upon their respective profile and accordingly suggest strategies to the investors to contain these biases and prevent them from making investment mistakes. This approach would help financial advisors to grasp the psychology of their clients proficiently and devise personality adjusted portfolios that suit their clients' psychology and predispositions and thus, help them build better relationships.

\section{REFERENCES}

Awang, Z. (2012). Structural Equation Modeling Using Amos Graphic. UiTM Press.

Banerjee, A. V. (1992). A Simple Model of Herd Behavior. The Quarterly Journal of Economics, 57(3), 797-817. Retrieved from https://economics.mit.edu/files/8869

Barber, B. M., \& Odean, T. (2000). Trading Is Hazardous to Your Wealth: The Common Stock Investment Performance of Individual Investors. The Journal of Finance, 55(2), 773-806. https://doi.org/10.1111/0022-1082.00226

Barber, B. M., \& Odean, T. (2001). Boys Will Be Boys: Gender, Overconfidence, and Common Stock Investment. Quarterly Journal of Economics, 116(1), 261-292. Retrieved from http://www.jstor.org/stable/2696449

Bashir, T., Fazal, S., Shabeer, I., Aslam, W., \& Jelani, G. (2013). Impact of Demographics and Personality traits on Confidence level: Determinants of Overconfidence (Evidence from employees and students). IOSR Journal of Business and Management, $\quad$ 10(1), 55-67. Retrieved from https://pdfs.semanticscholar.org/3ba5/0ef81f3fb40434f159de077121889e4918f4.pdf

Bayrakdaroglu, A., San, F. B., \& Oztop, A. O. (2015). Social Factors to Diminish Herding Behaviour : An Experimnent on Stock Preference. Proceedings of International Conference on Management,Economics and Social Sciences (pp. 77-83). Dubai. 
Retrieved from http://www.innovativeresearchpublication.com/documents/papers/dubai2015/pdf\%20 13.pdf

Bikhchandani, S., Hirshleifer, D., \& Welch, I. (1992). A Theory of Fads, Fashion, Custom and Cultural Change as Informational Cascades. Journal of Political Economy, 100(5), 992-1026. http://dx.doi.org/10.1086/261849

Block, R. A., \& Harper, D. R. (1991). Overconfidence in Estimation: Testing the Anchoringand-Adjustment Hypothesis. Organizational Behavior and Human Decision Processes, 49(2), 188-207. http://dx.doi.org/10.1016/0749-5978(91)90048-X

BSE, CMIE and Mint Calculations (n.d.). Retrieved from https://www.livemint.com/Money/kKNhSzmjqbQa7VOuLRWedJ/Majority-ofstates-have-very-few-stock-market-investors.html

Byrne, B. M. (1998). Structural Equation Modelling with LISREL, PRECIS, and SIMPLIS: Basic Concepts, Applications, and Programming. Mahwah, New Jersey: Lawrence Erlbaum Associates. https://doi.org/10.4324/9780203774762

Campbell, W. K., Goodie, A. S., \& Foster, J. D. (2004). Narcissism, Confidence, and Risk Attitude. Journal of Behavioral Decision Making, 17(4), 297-311. https://doi.org/10.1002/bdm.475

Campenhout, G. V., \& Verhestraeten, J. F. (2010). Herding Behavior among Financial Analysts: A Literature Review (HUB Paper 2010/39). Retrieved from https://core.ac.uk/download/pdf/34570401.pdf

Chaffai, M., \& Medhioub, I. (2014). Behavioral Finance: An Empirical Study of the Tunisian Stock Market. International Journal of Economics and Financial Issues, 4(3), 527-538. Retrieved from http://www.econjournals.com/index.php/ijefi/article/view/821

Charles, A., \& Kasilingam, R. (2014). Do Investors' Emotions Determine their Investment Personality? KIIT Journal of Management, 10(2), 45-60. Retrieved from http://www.publishingindia.com/GetBrochure.aspx?query=UERGQnJvY2h1cmVzfC 8yNDMxLnBkZnwvMjQzMS5wZGY=

Chaudhary, A. K. (2013). Impact of Behavoral Finance in Investment Decision and Strategies-A Fresh Approach. International Journal of Management Research and Business Strategy, 2(2), 85-92. Retrieved from http://citeseerx.ist.psu.edu/viewdoc/download?doi=10.1.1.740.3055\&rep=rep1\&type $=$ pdf

Durand, R. B., Newby, R., \& Sanghani, J. P. (2008). An Intimate Portrait of the Individual Investor. Journal of Behavioral Finance, 9(4), 193-208. https://doi.org/10.1080/15427560802341020

Durand, R. B., Newby, R., Peggs, L., \& Siekierka, M. (2013a). Personality. Journal of Behavioral Finance, 14(2), 116-133. https://doi.org/10.1080/15427560.2013.791294 
Durand, R., Newby, R., Tant, K., \& Trepongkaruna, S. (2013b). Overconfidence, Overreaction and Personality. Review of Behavioral Finance, 5(2), 104-133. https://doi.org/10.1108/RBF-07-2012-0011

Gaskin, J., \& Lim, J. (2016). Master Validity Tool, AMOS Plugin. Gaskination's StatWiki. Retrieved from http://statwiki.kolobkreations.com

Gigerenzer, G. U., Hoffrage, U., \& Kleinbolting, H. (1991). Probabilistic Mental Models: A Brunswikian Theory of Confidence. Psychological Review, 98(4), 506-528. Retrieved from http://library.mpib-berlin.mpg.de/ft/gg/gg_probabilistic_1991.pdf

Goldberg, L. R. (1992). The Development of Markers for the Big-Five Factor Structure. Psychological Assessment, 4(1), 26-42. Retrieved from https://projects.ori.org/lrg/PDFs_papers/Goldberg.Big-Five-Markers-

Psych.Assess.1992.pdf

Hair, J. F., Black, J. C., Babin, B. J., \& Anderson, R. E. (2010). Multivariate Data Analysis (7th ed.). Pearson.

Holden, K. (2010). The Emotions and Cognitions Behind Financial Decisions: The Implications of Theory for Practice. Working Paper 10-4, Center for Financial Security. $\quad$ Retrieved

from https://centerforfinancialsecurity.files.wordpress.com/2010/09/2010-the-emotionsand-cognitions-behind-financial-decisions-paper.pdf

Hu, L. T., \& Bentler, P. M. (1999). Cut-off Criteria for Fit Indexes in Covariance Structure Analysis: Conventional Criteria versus New Alternatives. Structural Equation Modeling: $\quad A \quad$ Multidisciplinary $\quad$ Journal, 6(1): 155. https://doi.org/10.1080/10705519909540118

Jamshidinavid, B., Chavoshani, M., \& Amiri, S. (2012). The Impact of Demographic and Psychological Characteristics on the Investment Prejudices in Tehran Stock. European Journal of Business and Social Sciences, 1(5), 41-53. Retrieved from http://ejbss.com/Data/Sites/1/augustissue/ejbss-12-1133-theimpactofdemographic.pdf

Jency, S. (2017). Impact of Investor's Personality Traits on Overconfidence Bias. International Journal of Management and Economics Invention, 3(8), 1307-1315. Retrieved from https://journals.indexcopernicus.com/api/file/viewByFileId/894473.pdf

John, O. P., \& Srivastava, S. (1999). The Big Five Trait taxonomy: History, Measurement, and Theoretical Perspectives. In L. A. Pervin, \& O. P. John (Eds.), Handbook of Personality: Theory and Research (pp. 102-138). New York, US: Guiford Press.

Kline, R. B. (2005). Principles and Practice of Structural Equation Modelling. New York: The Guilford Press.

Kubilay, B., \& Bayrakdaroglu, A. (2016). An Empirical Research on Investor Biases in Financial Decision-Making, Financial Risk Tolerance and Financial Personality. 
International Journal of Financial Research, 7(2), 171-182. Retrieved from http://www.sciedu.ca/journal/index.php/ijfr/article/viewFile/9284/5619

Lin, H. W. (2011). Elucidating the Influence of Demographics and Psychological Traits on Investment Biases. International Journal of Economics and Management Engineering, 5(5), 424-429. Retrieved from https://waset.org/publications/13900/elucidating-the-influence-of-demographics-andpsychological-traits-on-investment-biases

Odean, T. (1998a). Are Investors Reluctant to Realize Their Losses?. TheJournal of Finance, 53(5), 1775-1798. Retrieved from https://faculty.haas.berkeley.edu/odean/papers\%20current\%20versions/areinvestorsre luctant.pdf

Odean, T. (1998b). Volume, Volatility, Price and Profit When All Traders Are Above Average. The Journal of Finance, 53(6), 1887-1934. Retrieved from http://faculty.haas.berkeley.edu/odean/papers\%20current\%20versions/vvpp.pdf

Odean, T. (1999). Do Investors Trade Too Much?. American Economic Review, 89(5), 12791298. http://doi.org/10.2139/ssrn.219248

Pan, C. H., \& Statman, M. (2013). Investor Personality in Investor Questionnaires. Journal of Investment Consulting, 14(1), 48-56. Retrieved from https://papers.ssrn.com/sol3/papers.cfm?abstract_id=2235347

Pennings, J. M., \& Garcia, P. (2009). Risk and Herding Behavior: The Role and Determinants of Latent Hetrogeneity. The Journal of Financial Research, 33(4), 373401. https://doi.org/10.1111/j.1475-6803.2010.01279.x

Raheja, S., \& Dhiman, B. (2017). Does Investor Personality Determine their Risk Tolerance? International Journal of Engineering Technology, Management and Applied Sciences, 5(7), 439-448. Retrieved from http://www.ijetmas.com/admin/resources/project/paper/f201707171500305945.pdf

Rehan, R., \& Umer, I. U. (2017). Behavioural Biases and Investor Decisions. Market Forces, 12(2), 12-20. Retrieved from https://www.researchgate.net/publication/322745330_Behavioural_Biases_and_Inve stor_Decisions

Sadi, R., Asl, H. G., Rostami, M. R., Gholipour, A., \& Gholipour, F. (2011). Behavioral Finance: The Explanation of Investors' Personality and Perceptual Biases Effects on Financial Decisions. International Journal of Economics and Finance, 3(5), 234-241. Retrieved from http://www.ccsenet.org/journal/index.php/ijef/article/view/12337

Schaefer, P. S., Williams, C. C., Goodie, A. S., \& Campbell, W. K. (2004). Overconfidence and the Big Five. Journal of Research in Personality, 38(5), 473-480. Retrieved from http://psycnet.apa.org/doi/10.1016/j.jrp.2003.09.010

Scharfstein, D. S., \& Stein, J. C. (1990). Herd Behavior and Investment. American Economic Review, 80(3), 465-479. http://doi.org/10.1257/aer.90.3.695 
Schmitt, D. P., Allik, J., McCrae, R. R., Benet-Martinez, V. (2007). The Geographic Distribution of Big Five Personality Traits: Patterns and Profiles of Human Selfdescription across 56 Nations. Journal of Cross-Cultural Psychology, 38(2), 173212. Retrieved from http://www.toddkshackelford.com/downloads/Schmitt-JCCP2007.pdf

Shanmugham, R., \& Ramya, K. (2012). Impact of Social Factors on Individual Investors' Trading Behaviour. Procedia Economics and Finance, 2, 237-246. https://doi.org/10.1016/S2212-5671(12)00084-6

Shiller, R. J. (1987). Investor Behavior in the October 1987 Stock Market Crash: Survey Evidence (NBER Working Paper No. 2446). Retrieved from National Bureau of Economic Research website: Retrieved from https://www.nber.org/papers/w2446.pdf

Subrahmanyam, A. (2007). Behavioral Dinance: A Review and Synthesis. Europeon Financial Management, 14(1), 12-29. https://doi.org/10.1111/j.1468036X.2007.00415.x

Thomas, T., C. (2014). Big FivePersonality Traits and Behavioural Aspects of Individual Investors in Indian Capital Market. (PhD thesis, Anna University). Retrieved from http://hdl.handle.net/10603/49586

Winchester, D. D., Huston, S. J., \& Finke, M. S. (2011). Investor Prudence and the Role of Financial Advice. Journal of Financial Service Professionals, 65(4), 43-51. Retrieved from https://drive.google.com/file/d/0ByxIhlsExjE3ZzNLa2tDcjUtSms/edit

Yong, L. (2007). Emotional Excellence In The Workplace: LPI Personality Profiling. Kuala Lumpur, Malaysia: Leonard Personality Incorporated. Retrieved from http://www.leonard.com.my/pdf/ee\%20introduction.pdf

Zaidi, F. B., \& Tauni, M. Z. (2012). Influence of Investor's Personality Traits and Demographics on Overconfidence Bias. Interdisciplinary Journal Of Contemporary Research In Business, 4(6), 730-746. Retrieved from https://journalarchieves24.webs.com/730-746.pdf

\section{Copyrights}

Copyright for this article is retained by the author(s), with first publication rights granted to the journal. This is an open-access article distributed under the terms and conditions of the Creative Commons Attribution license (http://creativecommons.org/licenses/by/4.0/) 